DOI : 10.33451/florafauna.v26i1pp46-48

FLORA AND FAUNA

ISSN 2456 - 9364 (Online)

2020 Vol. 26 No. 1 PP 46-48

ISSN 0971 - 6920 (Print)

\title{
Studies on Fungal of Diseases of Cassia fistula and control measures in Nurseries and Plantation in Jalgaon District (M.S.) India
}

\section{S. A. Firdousi}

\author{
Department of Botany \\ H.J.Thim College of Arts and Science \\ Mehrun, JALGAON (MS) INDIA \\ Email : shakeel.talk@gmail.com
}

\section{Received : 25.02.2020; Accepted : 22.04.2020}

\begin{tabular}{l} 
ABSTRACT \\
During the extensive and intensive survey of the forest fungal disease of Cassia fistula growing in the road side, field, \\
scrub forest near natural forest, plantations and nurseries, about nine type of fungal and bacterial diseases were recorded \\
during 2017-2019. The diseases : wilt, leaf spot, leaf and stem rot were recorded in different study sites in the different \\
seasons. \\
The causal organism (Pathogens) were identified as Alternaria alternate, Fusarium solani, Phloespora cassia, \\
Ganoderma lucidum and Pseudo sercospora, \\
\hline Figure: 00 \\
KEY WORDS: Cassia fistula, Jalgaon
\end{tabular}

\section{Introduction}

Cassia fistula (Fabaceae) is an indigenous moderate size, deciduous tree with 12-15 feet height. It is known as Golden shower or Indian Laburn.. On account of its habit, it is being planted under the social forestry programme in the barren land and in the road side. It is very common in the natural deciduous forest. It is also grown in the garden for its beautiful yellow flower which appear during April-June. The plant is very important for its fuels, timber and medicinal importance. The bark of this plant is used for tanning in the leather industry. The root, bark, seeds and leaves are known to possess laxative property. It is used against inflammetary swelling and as cleaning agent. Purulent discharge and local antiseptic it expels the pitha and cough, diuretic

It is rich in carbohydrate, linoleic acid,oleic acid, stearic

\section{Material and Methods}

In order to collect phytopathogenic fungi and associated disease on Neem, a frequent survey was conducted in the forest and other places of Jalgaon ..The symptology and other information such as place of collection, locality, local names of the plant and date of collections were noted. The sample was kept in the polythene bag and brought in the laboratory. In the laboratory, host name was confirmed with the help of herbarium, Dept of Botany, Jalgaon (Maharashtra). Fungi which were saprophytic, was isolated in PDA medium after surface sterilization with $0.1 \%$ mercuric chloride and sterilized water. Tentative identification was done with the help of monographs and reference books and confirmed by experts.

\section{Conclusion}

A frequent surey was made to study the disease of Cassia fistula in the differtent study sites including nurseries and plantation and natural forest of Jalgaon District. The diseases were damping off, leaf web blight, leaf spot, leaf blight, powder mildew, bacterial leaf spot, seedling blight were recorded in different study sites in the different seasons. The causal organs (pathogens) were identified as Pseudosercospora, Alternaria, Oidium, Xanthomonas, Colletotrichum, Pythium, Phtophthora, Fusarium and Rhizoctonia. Control measures were suggested. 
Studies on Fungal of Diseases of Cassia fistula and control measures in Nurseries and Plantation in Jalgaon District (M.S.) India 47

TABLE -1 : Place, symptom, control measures of diseases of Cassia fistula

\begin{tabular}{|c|c|c|c|c|}
\hline S.N & Diseases & Place & Symptom & $\begin{array}{l}\text { Control measure } \\
\text { in Nuresies }\end{array}$ \\
\hline 1 & $\begin{array}{l}\text { Leaf Spot } \\
\text { disease by } \\
\text { Pseudo cercospora sp. }\end{array}$ & $\begin{array}{l}\text { Manudevi forest } \\
\text { Jalgaon }\end{array}$ & $\begin{array}{l}\text { The infection spots are brown } \\
\text { in color interspersed with white } \\
\text { patches. The fungus sporulates } \\
\text { on the under surface appear } \\
\text { grayish in mass. The heavily } \\
\text { infected leaves turn pale and } \\
\text { are shed prematurely. }\end{array}$ & $\begin{array}{l}\text { Application of } \\
\text { Mancozeb in } \\
\text { combination with } \\
\text { Brestan is found } \\
\text { effective in } \\
\text { controlling the } \\
\text { disease. }\end{array}$ \\
\hline 2 & $\begin{array}{l}\text { Leaf Spot disease } \\
\text { by Curularia sp. }\end{array}$ & Jalgaon & $\begin{array}{l}\text { Brown to black spot in the } \\
\text { both side of the leaf }\end{array}$ & $\begin{array}{l}\text { Application of } \\
\text { Mancozeb in } \\
\text { combination with } \\
\text { Brestan is found } \\
\text { effective in } \\
\text { controlling the } \\
\text { disease }\end{array}$ \\
\hline 3 & $\begin{array}{l}\text { Leaf Spot and } \\
\text { blight by } \\
\text { Alternaria alternata }\end{array}$ & & $\begin{array}{l}\text { It appears late in the growing } \\
\text { season in the last week. } \\
\text { It attacks the leaves when } \\
\text { the leaves become old }\end{array}$ & $\begin{array}{l}\text { Application of Biltox } \\
\text { fungicide }(0.2 \%)\end{array}$ \\
\hline 4 & $\begin{array}{l}\text { Leaf, twig and } \\
\text { stem rot by } \\
\text { Fusarium solani }\end{array}$ & $\begin{array}{l}\text { Manudeviforest } \\
\text { Jalgaon }\end{array}$ & $\begin{array}{l}\text { A severe leaf stem and } \\
\text { twig black rot. Disease } \\
\text { of plant was found in } \\
\text { the forest, Manudevi } \\
\text { forest Jalgaon }\end{array}$ & $\begin{array}{l}\text { Application of } \\
\text { Bavistin }(0.1 \%)\end{array}$ \\
\hline 5 & $\begin{array}{l}\text { Leaf spot aby } \\
\text { Phloespora cassiae }\end{array}$ & $\begin{array}{l}\text { Jk Park } \\
\text { Nursery of } \\
\text { Social } \\
\text { Forestery } \\
\text { Deptt. Jalgaon }\end{array}$ & $\begin{array}{l}\text { The symptom appears as } \\
\text { minute light spots which gradually } \\
\text { coalesce in due course. Spots are } \\
\text { more or less circular to irregular } \\
\text { brown to olove. Spot appears } \\
\text { on both surface of the leaves, } \\
\text { The pycnidia are subepedermal } \\
\text { and arranged in concentric ring. } \\
\text { The fungus causes leaf spots } \\
\text { which increase rapidly in size } \\
\text { covering large leaf areas. The } \\
\text { infected leaves preserve. Severely } \\
\text { infected seedlings show premature } \\
\text { defoliation. The disease appears } \\
\text { in the months of september to } \\
\text { February. }\end{array}$ & $\begin{array}{l}\text { Application of Biltox } \\
\text { fungicide }(0.2 \%)\end{array}$ \\
\hline 6 & $\begin{array}{l}\text { Wilt diseaes by } \\
\text { by Fusarium sp. }\end{array}$ & $\begin{array}{l}\text { Jk Park Nursery } \\
\text { of Social forestery } \\
\text { Deptt. Jalgaon }\end{array}$ & $\begin{array}{l}\text { Among the nursery diseases, wilt } \\
\text { is the most prevalent and highly } \\
\text { destructive disease and causes } \\
\text { heavy disease namely pre- } \\
\text { emergence and post-emergence } \\
\text { damping off depending on the } \\
\text { state of growth of seedling }\end{array}$ & $\begin{array}{l}\text { Formalin and } \\
\text { Bavistin }\end{array}$ \\
\hline
\end{tabular}




\begin{tabular}{l|l|l|l|l}
\hline S.N & Diseases & Place & Symptom & $\begin{array}{l}\text { Control measure } \\
\text { in Nuresies }\end{array}$ \\
\hline 7 & $\begin{array}{l}\text { Stem and basal rot } \\
\text { by Ganoderma lucidum }\end{array}$ & $\begin{array}{l}\text { Open field around } \\
\text { and road side } \\
\text { plantation Jalgaon }\end{array}$ & $\begin{array}{l}\text { Stem and basal rot by Ganoderma. } \\
\text { Complete tree wilted, dried and } \\
\text { killed. }\end{array}$ & $\begin{array}{l}\text { Eradication in } \\
\text { young and early } \\
\text { stage stage. }\end{array}$ \\
\hline
\end{tabular}

\section{References}

1. Bakshi BK. Forest Pathology : Principal and Practice I Forestry, Controller of Publication Delhi. 1976.

2. Ellis MB. More Dematiceous Hypomycetes CMI Kew England. 1976.

3. Firdousi SA, Khan TA. Two new fungal diseases of trees of Manudevi forest of Jalgaon. Flora and Fauna. 2015; 21(2) : 158-160

4. Jamaluddin Rizvi, Bilgrami. Fungi of India host Index and Addenda, Bisen Pal Singh Publication, Dehradun. 2008. 